\title{
THE MEASUREMENT OF CONSUMER GREEN PURCHASE INTENTION DETERMINANTS TOWARD HYBRID CARS IN MALAYSIA
}

\author{
SITI SALWANI MEOR AHMAD ${ }^{1}$, NOOR AZMAN ALI ${ }^{2 *}$ \\ ${ }^{1}$ Putra Business School, Universiti Putra Malaysia, Serdang, Selangor, Malaysia. ${ }^{2}$ School of Business and Economics, Universiti Putra \\ Malaysia, Serdang, Selangor, Malaysia. Email: nazman@upm.edu.my
}

Received: 30 October 2020, Revised and Accepted: 27 November 2020

\section{ABSTRACT}

Transportation is acknowledged as one of the major sources of greenhouse gasses and air pollution. Thus, promoting cars with high efficiency in fuel consumption and reduce emission is required to replace conventional cars. In that case, encouraging consumer to purchase green car by identifying factors that affect green car purchase intention among Malaysian is important. This study provides some preliminary evidence on determinants of hybrid cars purchase intentionin Malaysia and green product attachment as a mediator.Hence, the validity and reliability of instrument were examined via pretest and a pilot test. The data normality also waschecked by using SPSS version 21 . The findings suggest that the Green Trust and Green Product Attachment are the most significant factors on the influence toward Green Purchase Intention of hybrid cars in terms of reliability score.

Keywords: Green product attachment, Green purchase intention, Hybrid cars.

\section{INTRODUCTION}

Today, the world is witnessing a lot of environmental issues at the global level, such as environmental degradation, global warming, ozone depletion, and climate change. All these environmental problems have significant consequences on human wellbeing and quality of life [1]. The high fossil fuel usage and consumption in transportation increase the emission of pollutants causing the emission of the greenhouse effect that can cause global warming $[2,3]$. The fact is, the transportation system brings a massive impact on the country's socio-economic development especially in Malaysia. In directing to achieve developed country status and preserve the environment, Malaysia is committed to this transition toward sustainability and aims to reduce the emission of carbon dioxide $\left(\mathrm{CO}_{2}\right)$. Hence, the environmental issue will have to be resolved with advanced technology and environmental policy. In line with the National Automotive Policy (NAP) 2014 objectives, some options that the automotive industry can adopt are by introducing cleaner fuels and technologies or adjusting technologies to produce green vehicles such as electric car, hybrid electric vehicle (HEV), natural gas vehicle (NGV), and other alternative fuel vehicles. Shifting toward carbon reduction can be done through behavioral intervention. Therefore, green marketers should have a better insight into consumer purchase intention. Purchase intention is part of the consumer decisionmaking process that stimulates consumers to purchase a product in their purchase consideration [4]

Green purchase intention is defined as consumer consideration to purchase a product that has eco characteristics [5]. On the other hand, Chen and Chang [6] conceptualized green purchase intention as a consumer willingness to buy specific products that meet the environmental needs. One of the popular theories that explain behavioral intention is the Theory of Planned Behavior (TPB). Based on the TPB, attitudes, subjective norms, and perceived behavioral controls are formed as predictors of intention [7]. Many firms use purchase intention in forecasting new product sales, and repurchase an existing product, or forming marketing strategies $[8,9]$.

The determinants of green purchase intention are green knowledge, green trust, green pricing, and social influence. Green knowledge has been viewed as people's knowledge or understanding of the ecosystem and environmental impact [10]. Knowledge is linked with the cognitive process whereby commonly knowledgeable people will understand the situation and help them decide on particular issues [11]. However, the consumer-level of product knowledge will impact their information and decision-making.

According to Chen [12], green trust is consumer belief that goods have credibility, benevolence, and the ability to protect the environment. In other words, the product or brand that has eco-attributes, green benefits, or safe for the environment may gain consumer trust. One of the alternatives to lead green behavior is by increasing consumer trust [13]. On the other hand, a good green pricing strategy should be applied by taking into consideration of environment and consumer willingness to purchase as the price is a main perceived hurdle to buy a green product [14]. Consumer willingness to purchase is defined as the maximum price that consumer willing to spend on a certain quantity of green products [15].

On another aspect related to green marketing, social influence is a person or group that influence other people, where someone follows and accepts other's expectations and information [16,17]. Social influence role is crucial in sustainability behavior because environmental issues are abstract and less instantaneous. Hence, by looking at other's reactions is a way to get immediate feedbacks [18]. In contrast, Gupta and Ogden [19] claimed individual will conform to group norms with the condition she or he has a higher trust in others.

Green product attachment is an emotional bonds that consumer experiences toward environmentally-safe products [20]. On the subject of sustainability, green product attachment can be elucidated as an emotional tie that encounters between a person and a green product. Happiness, joy, security, anxiety, anger, and sadness are the types of emotions that people feel toward a product. That emotional attachment felt by the consumer may occur along any buying process, starting from the pre-purchase phase, buying phase, and post-purchase phase [21]. This is acknowledged earlier by Desmet and Hekkert [22] as feeling toward a product aesthetic may present before the product is bought. Besides, product attachment is developed from consumer interaction with the product. That makes sense why it could determine individual behavioral motivations and intentions toward the object [23]. A consumer who is emotionally attached to the product tends to purchase, spread the word of mouth, repurchase, revisit, patronage, and invest in the attached product or brand $[24,25]$. 
The pre-test and pilot test is conducted as preparation for the main study. The variables of green knowledge, green trust, green pricing, and social influence are selected as researches on that variables are still lacking and suffer from the uncertainties conclusions in the context of green and Malaysia. Thus, the rationale of the study is to ensure that particular research instruments are reliable and valid. However, many researchers just ignore conducting a pilot test, and unnoticed that both tests have different purposes $[26,27]$.

\section{METHODS}

\section{Pre-test and pilot test}

A pre-test was conducted with two academicians and three postgraduate scholars from business and sustainability areas to evaluate the content validity. The idea is to get experts' judgments of how well each questionnaire item reflects the construct that is supposed to measure [28]. Based on the input during a pre-test, the questionnaire was fine-tuned, and then the questionnaire was pilot tested toward 50 non-hybrid and hybrid car owners. A filter question "Do you drive your own car?" was asked to qualify the respondents. An adjustment was made afterward before the questionnaire was distributed in the actual field.

A pilot test is the first step in all types of research studies and a vital prerequisite before leading to the actual study as it is the best way to assess the feasibility of a large, expensive full-scale study. According to Hazzi and Maldaon [26], a pilot study is not used for hypothesis testing, and somehow it is crucial to ensure the quality of this research is established.

\section{The instrument and measurement}

The research instrument used for this study is the questionnaire. This questionnaire consisted of closed-ended questions and was divided into four sections. In the first section, the profile of the respondent was developed. The second section concerned the determinants of green purchase intention. The determinants were green knowledge (GK), green trust (GTrust), green pricing (GPricing), and social influence (SocInf). It was developed by the researcher through adopting and modifying the construct found for green trust [12], subjective and objective green knowledge [29-31], social influence [32], and green pricing [33]. The third section was involved the mediator of the study; green product attachment (GProAttach) [34]. Finally, the fourth section on green purchase intention (GPurchInten) was developed based on previous studies of Rizwan, Asif, Hussain, Asghar, Hassan, and Javeed [35] and Kabadayi, Dursun, Alan, and Tugar [36]

Respondents were asked to indicate their level of agreement for each statement using a 7-point Likert scale anchored from "1-strongly disagree" to "7-strongly disagree". Selecting the 7 points itemized scale was preferred since this 7 -point scale enabled the respondents to show their stand comfortably and precisely.

The key variables contained in the study were green knowledge, green trust, social influence, green pricing, green product attachment, and green purchase intention. All the variables were uni-dimensional except green knowledge. Accordingly, the questionnaire of this research is made up of four sections. Section 1 comprised questions about the demographic information of the respondents. Section 2 consisted of seven questions that seemed to measure the level of respondent knowledge regarding the environmental issues and the impact of a product toward the environment, five questions that were directed to measure green trust, three questions that were targeted to evaluate green pricing as perceived by the respondents, and five items to assess social influence among respondents. Section 3 contained five questions of green product attachment and finally, Section 4 comprised six questions that evaluated consumer purchase intentions.

\section{RESULTS}

\section{Profile of the respondents}

The demographic characteristics of the respondents are in Table 1 . The majority of respondents were female (56\%). Most of the respondents were aged between 29 and 39 years. More than half of the sample $(56 \%)$ had postgraduate education. About $68 \%$ of respondents were

Table 1: Socio-demographic characteristics profiles of respondents

\begin{tabular}{|c|c|c|}
\hline Variable & Frequency & Percentage \\
\hline \multicolumn{3}{|l|}{ Gender } \\
\hline Male & 22 & 44 \\
\hline Female & 28 & 56 \\
\hline \multicolumn{3}{|l|}{ Age } \\
\hline $18-28$ & 5 & 10 \\
\hline $29-39$ & 24 & 48 \\
\hline $40-50$ & 17 & 34 \\
\hline $51-61$ & 3 & 6 \\
\hline Above 61 & 1 & 2 \\
\hline \multicolumn{3}{|l|}{ Employment } \\
\hline Professional & 34 & 68 \\
\hline Managerial & 5 & 10 \\
\hline Support staff & 7 & 14 \\
\hline Self-employed & 3 & 6 \\
\hline Other & 1 & 2 \\
\hline \multicolumn{3}{|l|}{ Education } \\
\hline SPM/SPMV & 4 & 8 \\
\hline STPM/Diploma/Certificate & 10 & 20 \\
\hline Bachelor & 8 & 16 \\
\hline Post Graduate & 28 & 56 \\
\hline \multicolumn{3}{|c|}{ Household gross income (in Ringgit Malaysia) } \\
\hline Less than RM 3000 & 14 & 28 \\
\hline RM 3001- RM 5000 & 12 & 24 \\
\hline RM 5001- RM 7000 & 17 & 34 \\
\hline RM 7001- RM 9000 & 1 & 2 \\
\hline RM 9001- RM 11000 & 2 & 4 \\
\hline More than RM 11000 & 4 & 8 \\
\hline
\end{tabular}


professional and 34\% of the respondents had household gross income from RM 5001 to RM 7000. The details are stated in Table 1.

In summary, Table 2 shows that most of the respondents have considered buying a hybrid car and about $82 \%$ of them have thought about buying petrol and electric type of car.

Table 3 shows the overall mean and standard deviation (SD) for 31 items. These items have means higher than 3 , whereas the means were ranged from 3.98 to 5.86 . The lowest SD was 0.832 and the highest SD was 1.918 . The figures indicated that all the data were concentrated around the means.

\section{Data distribution}

Most inferential statistical techniques require the fulfillment of the normality assumption. There are several methods to see whether continuous data are distributed normally. In general, the normality assumption can be evaluated by graphical and test methods. Graphical methods such as histogram, stem-and-leaf plot, box plot, normal probability plot, and detrended normal plot provided information with the shape of a distribution. Furthermore, Kolmogorov-Smirnov statistic, Shapiro-Wilk statistic, skewness, and kurtosis are available tests for normality.

This study used values of skewness and kurtosis. The skewness explains the symmetry, while kurtosis shows which data are peak or flat. According to Curran, West, and Finch [37], the value for skewness and kurtosis shall be \pm 2.0 and \pm 7.0 , respectively. Notwithstanding, Kline [38] argues that the skewness value within \pm 3 and kurtosis value between \pm 10 are considered normal data. The skewness of all items was ranged from -1.367 to +2.412 , below \pm 3 and the values for kurtosis ranged from -2.020 to +3.974 , far $< \pm 10$. Thus, considering the suggestion above, the data used in the study were normally distributed.

Table 2: Respondents reactions to the hybrid car

\begin{tabular}{lll}
\hline Variable & Frequency & Percentage (\%) \\
\hline Category of respondents: & & \\
$\quad$ Considered buying a hybrid car & 44 & 88 \\
Purchased a hybrid car & 6 & 12 \\
Types of the hybrid car considered & & \\
to purchase: & 41 & 82 \\
Petrol and electric & 9 & 18 \\
Petrol and natural gas & - & - \\
Other &
\end{tabular}

Not all statistical analysis is valid for non-normal distribution data. The proof of normality data must be attained before employing any parametric test like t-test, analysis of variance (ANOVA), and Pearson correlation. Otherwise, non-parametric tests such as Chi-square, Mann-Whitney test, Kruskal-Wallis test, Friedman test, and Spearman correlation can be used if the data are not a normal distribution $[26,39]$. Failure to identify data distribution may lead to the wrong selection of tests and results.

\section{Validity and reliability of the instrument}

The items were selected from questionnaires that were validated in previous studies for use in the present study. In this study, the literature was extensively reviewed from journals in the field of retailing, sustainability, and marketing. The items of the questionnaire were adopted and adapted from existing scales in the literature. Questionnaire content validity was evaluated by two academicians and three scholars from the sustainability, and marketing disciplines. A few changes were made according to the experts' comments and suggestions. One item in green purchase intention was deleted due to the repeated meaning with another item.

Then, to assess questionnaire reliability, the pilot study was conducted on a convenience sample of 50 hybrid and non-hybrid car owners in Kuala Lumpur. This resulted in several sentences were rephrased and reworded to make it easier to understand by respondents before distributed in the actual field. It is important to find reliable scales. According to Pallant [39], the reliable scale indicates that it is free from random error. Scale reliability can be explained using the indicators such as test-retest reliability and internal consistency. Even though the test-retest correlations are more reliable due to the tests that are run on two different events with the same people, commonly Cronbach alpha coefficient is used to test inter-item consistency reliability. Hence, this study employed the Cronbach alpha test to measure the internal consistency of the instrument that explains how extensive to which the items "hang together."

The reading for all constructs is indicated in Table 4. The constructs had scores ranging from 0.722 to 0.903 , which exceeded the recommended minimum level of 0.7 , and indicated the high internal consistency reliability [40].

\section{DISCUSSION}

The green concept in Malaysia is still new. Thus, the TPB is selected to predict the determinants of purchase intention, and the aspect of emotion is assessed by specifically emphasizing green product attachment. Although, the survey instrument items were adopted and adapted from the previous studies. These developed items or scales should be pre-tested to ensure the questions work well in new respondents and setting [41]. Recently, more studies have discussed

Table 3: Mean and standard deviation of the items

\begin{tabular}{|c|c|c|c|c|c|}
\hline Item & Mean & Standard deviation & Item & Mean & Standard deviation (SD) \\
\hline GK8 & 5.80 & 0.926 & SocInf24 & 4.90 & 0.995 \\
\hline GK9 & 5.50 & 0.839 & SocInf25 & 4.76 & 1.001 \\
\hline GK10 & 5.04 & 0.832 & SocInf26 & 4.30 & 1.403 \\
\hline GK11 & 5.84 & 1.037 & SocInf27 & 4.64 & 1.191 \\
\hline GK12 & 5.18 & 1.273 & GProAttach28 & 4.60 & 1.050 \\
\hline GK13 & 5.60 & 1.143 & GProAttach29 & 4.10 & 1.403 \\
\hline GK14 & 5.42 & 1.197 & GProAttach30 & 3.98 & 1.478 \\
\hline GTrust16 & 5.48 & 0.886 & GProAttach32 & 4.40 & 1.340 \\
\hline GTrust17 & 5.42 & 0.992 & GPurchInten39 & 5.22 & 1.166 \\
\hline GTrust18 & 5.12 & 0.849 & GPurchInten 40 & 5.42 & 1.012 \\
\hline GTrust19 & 5.14 & 0.833 & GPurchInten41 & 4.44 & 1.918 \\
\hline GPricing20 & 5.14 & 1.278 & GPurchInten 42 & 5.86 & 1.125 \\
\hline GPricing21 & 4.72 & 1.213 & GPurchInten43 & 5.44 & 0.951 \\
\hline GPricing22 & 5.04 & 1.293 & GPurchIntent44 & 5.78 & 1.093 \\
\hline SocInf23 & 4.98 & 1.059 & & & \\
\hline
\end{tabular}

The questionnaire scales from 1 (strongly disagree) to 7 (strongly agree) 
Table 4: Cronbach alpha values

\begin{tabular}{lll}
\hline Construct & $\begin{array}{l}\text { Cronbach } \\
\text { alpha }\end{array}$ & $\begin{array}{l}\text { Number of } \\
\text { questions }\end{array}$ \\
\hline Green knowledge & 0.80 & 7 \\
Green trust & 0.90 & 5 \\
Green pricing & 0.85 & 3 \\
Social influence & 0.72 & 5 \\
Green product attachment & 0.91 & 5 \\
Green purchase intention & 0.75 & 6 \\
\hline
\end{tabular}

and emphasized the importance of conducting a pre-test and pilot study $[26,42]$. Based on the analysis of the small data during the pilot test, the data as a whole were considered normal. All variables had strong consistency.

Even though the subject of the study is the intention to purchase hybrid cars, which is a car often related to masculinity. The male respondents were preceded by female. The majority of the respondents also considered buying petrol and electric type of car rather than petrol and natural gas (bi-fuel NGVs) type. Another study also identified respondents' willingness to change their conventional car to NGV was very low and with certain conditions [43]. Another socio-demographic characteristic such as household income also is seen as one of the factors why consumer avoids the green product, especially in Malaysia [44]. The majority of the respondents (34\%) had household gross income from RM 5001 (USD 1223) to RM 7000 (USD 1712). That range explained the respondents were in average income category. In fact, consumer resources such as money may act as consumer control in performing the behavior [7]. In Malaysia, car prices are expensive due to the high duties and taxes levied. Thus, respondent's willingness to pay needed attention as the price is an important parameter when buying a green car [45]. Indeed, both low and high income householders will take a different direction toward sustainable behavior.

\section{CONCLUSION}

The purpose of this study is to explore small sample data on the determinants of green purchase intention in Malaysia. The data were collected during the pilot test. The validity and reliability of the instrument were assessed in preparation for the large scale study. The managerial implication of the variables will be mentioned in the actual study. The content validity was evaluated which ended-up in removing of one item due to similarity with another item and reworded several items. The inter-item reliability test showed all the items were reliable as the Cronbach alpha value exceeded the benchmark of 0.7. Thus, all items were retained. Finally, the result of skewness and kurtosis suggested that the data were normal.

\section{CONFLICTS OF INTEREST}

There are no conflicts of interest regarding the publication of this paper.

\section{REFERENCES}

1. Subramani SS. Application of air pollution tolerance index in assessing the air quality. Int J Pharm Pharm Sci 2015;7:216-21.

2. Afroz R, Masud MM, Akhtar R, Islam MA, Duasa JB. Consumer purchase intention towards environmentally friendly vehicles: An empirical investigation in Kuala Lumpur, Malaysia. Environ Sci Pollut Res Int 2015;22:16153-63.

3. Aini MS, Chan SC, Syuhaily O. Predictors of technical adoption and behavioural change to transport energy-saving measures in response to climate change. Energy Pol 2013;61:1055-62.

4. Hassan SH. The role of Islamic values on green purchase intention. J Islam Mark 2014;5:379-95.

5. Rashid NR. Awareness of eco-label in Malaysia' s green marketing initiative. Int J Bus Manag 2009;4:132-41.

6. Chen YS, Chang CH. Enhance green purchase intentions: The roles of green perceived value, green perceived risk, and green trust. Manag
Decis 2012:50:502-20.

7. Ajzen I. The theory of planned behavior. Organ Behav Hum Decis Process 1991;50:179-211.

8. Ali A, Khan AA, Ahmed I, Shahzad W. Determinants of Pakistani consumers' green purchase behavior : Some insights from a developing country. Int J Bus Soc Sci Res 2011;2:217-26.

9. Zheng Y, Chi T. Factors influencing purchase intention towards environmentally friendly apparel: An empirical study of US consumers. Int J Fash Des Technol Educ 2014;8:68-77.

10. Fryxell GE, Lo CW. The influence of environmental knowledge and values on managerial behaviours on behalf of the environment: An empirical examination of managers in China. J Bus Ethics 2003;46:45-69

11. Katu VM, Mat NK. The mediating effects of green trust and perceived behavioral control on the direct determinants of intention to purchase green products in Nigeria. Med J Soc Sci 2015;6:256-65.

12. Chen YS. The drivers of green brand equity: Green brand image, green satisfaction, and green trust. J Bus Ethics 2010;93:307-19.

13. Joshi Y, Rahman Z. Factors affecting green purchase behaviour and future research directions. Int Strateg Manag Rev 2015;3:128-43.

14. Aschemann-Witzel J, Zielke S. Can't buy me green? A review of consumer perceptions of and behavior toward the price of organic food. J Consum Aff 2017;51:211-51.

15. Koschate-Fischer N, Stefan I, Hoyer WD. Willingness to pay for causerelated marketing: The impact of donation amount and moderating effects. J Mark Res 2012;49:910-27.

16. Deutsch M, Gerard HB. A study of normative and informational social influences upon individual judgement. J Abnorm Soc Psychol 1955;51:629-36.

17. Yalew YT. The role of social support and some selected sociodemographic variables in promoting the identity achievement of young adults: The case of students in gondor college of teacher education. Innovare J Soc Sci 2018;5:1-7.

18. Ozaki R. Adopting sustainable innovation: What makes consumers sign up to green electricity? Bus Strat Environ 2011;20:1-17.

19. Gupta S, Ogden DT. To buy or not to buy? A social dilemma perspective on green buying. J Consum Mark 2009;26:378-93.

20. Schifferstein HN, Zwartkruis-Pelgrim EP. Consumer-product attachment: Measurement and design implications. Int $\mathrm{J}$ Des 2008;2:1-13.

21. Koshkaki ER. The role of product and brand emotion in purchase behavior, a study in Iranian home appliance context. J Asia Bus 2014;8:233-48.

22. Desmet PM, Hekkert PP. The basis of product emotions. In: Green W, Jordan P, editors Pleasure with Products: Beyond Usability. London: Taylor \& Francis; 2002. p. 60-8.

23. Bowlby J. The Making and Breaking of Affectional Bonds. London: Tavistock; 1979.

24. Kaufmann HR, Petrovici DA, Filho CG, Ayres A. Identifying moderators of brand attachment for driving customer purchase intention of original vs counterfeits of luxury brands. J Bus Res 2016;69:5735-47.

25. Badrinarayanan V, Becerra EP. Shoppers' attachment with retail stores: Antecedents and impact on patronage intentions. J Retail Consum Serv 2019;50:371-8.

26. Hazzi OA, Maldaon IS. A pilot study : Vital methodological issues. Bus Theory Pract 2015;16:53-62.

27. Memon MA, Ting H, Ramayah T, Chuah F, Cheah JH. A review of the methodological misconceptions and guidelines related to the application of structural equation modeling: A malaysian scenario. J Appl Struct Equ Mod 2017;1:1-13.

28. Malhotra NK, Birks DF. Marketing Research: An Applied Approach. United Kingdom: Pearson Education Limited; 2006.

29. Yavetz B, Goldman D, Pe'er S. Environmental literacy of pre-service teachers in Israel: A comparison between students at the onset and end of their studies. Environ Educ Res 2009;15:393-415.

30. Mostafa MM. Antecedents of Egyptian consumers' green purchase intentions. J Int Consum Mark 2006;19:97-126.

31. Carmi N, Arnon S, Orion N. Transforming environmental knowledge into behavior: The mediating role of environmental emotions. J Environ Educ 2015;46:183-201.

32. Lee K. Opportunities for green marketing: Young consumers. Mark Intell Plan 2008;26:573-86.

33. Garg A. Green marketing for sustainable development: An industry perspective. Sustain Dev 2015;23:301-16.

34. Mugge R, Schifferstein HN, Schoormans JP. Product attachment and satisfaction: Understanding consumers' post-purchase behavior. J Consum Mark 2010;27:271-82. 
35. Rizwan M, Asif RM, Hussain S, Asghar M, Hassan M, Javeed U. Future of green products in Pakistan: An empirical study about green purchase intentions. Asian J Empir Res 2013;3:91-207.

36. Kabadayi ET, Dursun I, Alan AK, Tuger AT. Green purchase intention of young Turkish consumers: Effects of consumer's guilt, selfmonitoring and perceived consumer effectiveness. Proc Soc Behav Sci 2015;207:165-74

37. Curran PJ, West SG, Finch JF. The robustness of test statistics to nonnormality and specification errors in confirmatory factor analysis Psychol Methods 1996;1:16-29.

38. Kline RB. Principles and Practice of Structural Equation Modeling. New York: Guilford Press; 2010.

39. Pallant J. SPSS Survival Manual: A Step By Guide To Data Analysis Using SPSS For Windows (version 12). Sydney: Allen \& Unwin; 2005.

40. George D, Mallery P. SPSS For Windows Step By Step: A Simple
Guide And Reference. Boston: Pearson Education; 2003

41. Kumar M, Talib SA, Ramayah T. Business Research Methods. Selangor, Malaysia: Oxford University Press; 2013.

42. Thabane L, Ma J, Chu R, Cheng J, Ismaila A, Rios LP, et al. A tutorial on pilot studies: The what, why and how. BMC Med Res Methodol 2010;10:1-10.

43. Jayaraman K, Haron H, Feng CK, Yusof N, Agbola F. Determinants of the intention to use natural gas vehicle (ngv) as an alternative to a petrol car: The case of Malaysia. J Sustain Sci Manag 2015;10:36-49.

44. Al Mamun A, Fazal SA, Ahmad G, Yaacob MR, Mohamad MR. Willingness to pay for environmentally friendly products among lowincome households along coastal peninsular Malaysia. Sustainability 2018;10:1316.

45. Joshi N, Rao PS. Environment friendly car: Challenges ahead in India. Glob J Manage Bus Res Interdiscip 2013;13:10-9. 